\title{
Time Preference and Readiness of Farm Women for ICT Usage
}

\author{
Neela Rani and Uma Jyothi* \\ All India Coordinated Research Project on Home Science Extension, Professor Jayashankar \\ State Agricultural University, Hyderabad-30, India \\ *Corresponding author
}

\section{A B S T R A C T}

\section{Keywords}

ICT Needs, Time

Preference,

Readiness

Article Info

Accepted:

30 May 2020

Available Online:

10 June 2020
Primary occupation of India is agriculture and rural areas are quite concerned with this occupation. There are various aspects on which the rural development is based on agriculture, improving standard of living, imparting education, women empowerment and many more. Information sharing of new production processes with farmers was prominent in the sixties which was the key to the success of the green revolution. Rural economies can be benefitted from ICT by focusing on social production, social consumption and social services in rural areas (Malhotra, 2001). "ICT" concentrates on these three words: Information, Communication and Technology; to promote information via communication with the help of technology. ICT acts as a catalytic intervention for empowering rural India as it accelerates economic development in rural areas by helping the people in accessing the information in order to bridge the gap. Access to relevant information and knowledge is crucial and ICTs can be useful in this process to a great extent. ICT has been seen as major tool for rural development as it has the potential to effectively address issues like health, Education, Agricultural productivity, Agribusinesses- Governance, risk management, access to knowledge, women empowerment etc. This article presents findings based on fieldwork conducted by the authors at Nagireddyguda village, Moinabad Mandal, Ranga Reddy District. The study observes the media usage and preference of use for agriculture and nonfarm employment information.

\section{Introduction}

Reflection on the decades of development work has shown that failure to empower women will hinder efforts to alleviate global poverty. But because of their historical roles, women are generally more bound to their localities and have had less access to the emerging pool of empowering knowledge. ICTs and engendered knowledge networks can help to overcome these disadvantages.
Information and communication technology is the powerful and productive systems that transform all human activities, including rural economy. Rural economies can be benefitted from ICT by focusing on social production, social consumption and social services in rural areas (Malhotra, 2001).

Munyua (2000) observed that lack of reliable and comprehensive information for rural female farmers in Delta State is a major 
hindrance of agricultural development. They require information on agricultural inputs, market prices, transportation systems; environmental sound production techniques and practices; new agricultural technologies; food processing and preservation; decisionmaking process; trade laws and trends in food production.

In developing country like India, ICT revolution renders rural population to become an active participant in growth of our country. ICTs refer to technologies that provide access to information through telecommunications. It is similar to Information Technology (IT), but focuses primarily on communication technologies. This includes the Internet, wireless networks, cell phones, and other communication mediums to enhance capabilities of people. The rural development is one of the important factors for the growth of Indian economy. ICT is a major tool to leverage the scheme for ensuring access to the target group of beneficiaries. It is rather a powerful tool to tackle development challenges. ICT facilitate new techniques of presentation - because of the flexibility and interactivity of the medium and the possibility of adapting it to the social context. That makes it easier to reach women across the world, speaking various languages and at various levels of education and skills. The benefits of ICT may bypass women even if their countries develop adequate information infrastructure and service delivery (Marcelle, 2000).

\section{Materials and Methods}

Rank Based Questionnaire (RBQ) was the instrument used for collection of data for this study. The first section pursued demographic data while the second section contained structured items that were developed through extensive review of literature in order to ensure content validity of the instrument. The sample population was made up of both genders of farmers from the village. The researchers administered the questionnaire to get the media usage pattern of the people and the time preference of media usage in Agriculture information as well nonfarm employment information. Data from 90 farmers and farm women was collected through Participatory need assessment and prioritization of information needs of farm women in agriculture through PRA tools \& techniques, personal interview\& Focus Group Discussions in Nagireddyguda village, Moinabad Mandal, RR District. Assessment of information needs of farm women and men in Agriculture and their readiness for e-extension was done.

PRA tools \& techniques for information need assessment,

Capacity building for imparting Computer Skills Capacity building for information sharing and agribusiness through internet and web browsing.

\section{Results and Discussion}

The table 1 reveals that fifty percent $(40 \%)$ of the respondents belongs to $\mathrm{BC}$ community and 20 percent belonged to other castes. More than forty percent $(46.80 \%)$ of them belonged to nuclear families and only thirty (34\%) are into joint families. More than fifty percent $(55.80 \%)$ of respondents are taking up farming as main occupation, 25 per cent of them have daily wage earning as subsidiary occupation. Fifty percent $(54.33 \%)$ of them from small land holding and 30percent of them are from medium land hold category, the area under paddy cultivation 42 per cent of them are cultivating rice in 1.5 acres (Fig. 1). The livestock ownership reveal that majority of them belongs to small category followed by 36 per centMedium 27 per cent and only 18 per cent of them belong to high category, since maintenance of 
livestock was riskier and besides farming it is difficult to them to manage, as it involves two members per day compulsorily to attend to the chores of livestock maintenance.

Results revealed that the media usage by literate farmers for getting farming information was Television comes first 89.56 per cent, followed by News Papers $(49.16 \%)$, whereas the computers falls last $(12.79 \%)$ by the literate Farmers.

While upcoming to the Illiterates usage of Television as well falls first with $(99.43 \%)$ followed by Cell phone $(53.71 \%)$ whereas the videos comes the last usage with $(5.14 \%)$ (Table 2).

From Table 3, preference of media usage revealed that T.V (78.30\%) firstly preferred media by both the literates as well illiterates as it is their merely cheapest source of entertainment in the necessary timings followed by computer $(60 \%)$. Young users were found to use the Internet more frequently for chatting and entertainment than older ones. Whereas Radio (22.50\%) was the last preferred means of media as it is considered as the out dated source by the youth and young farmers. Respondents were less keen to know about political matters. Some of them attributed their decision to the relaxed attitude of the local, state and federal governments towards their socio-economic needs. It can be concluded that the rural female farmers were very keen to know more about crops, production and their market price etc. This may be because crop production is the major source of their income. Time preference for obtaining information and accessing computers was also evolved and suitable time preferred by farm women was evenings from $7 \mathrm{pm}$ to $9 \mathrm{pm}$ along with their children.

Table.1 Socio economic status of the respondents

\begin{tabular}{|c|c|c|c|}
\hline Characteristics & Categories & $\begin{array}{c}\text { Number of } \\
\text { respondents }\end{array}$ & Percentage\% \\
\hline \multirow{2}{*}{ caste } & SC & 25 & \\
\hline & BC & 45 & $\mathbf{2 2 . 2 5}$ \\
\hline Family Type & OC & 20 & $\mathbf{4 0 . 5}$ \\
\hline & Nuclear & 52 & $\mathbf{1 8 . 0}$ \\
\hline Occupation & Joint & 38 & $\mathbf{3 4 . 2}$ \\
\hline Main occupation & Farming & 62 & $\mathbf{5 5 . 8}$ \\
\hline & Daily wager & 28 & $\mathbf{2 5 . 2 0}$ \\
\hline Subsidiary occupation & Farming +Daily wager & 90 & $\mathbf{1 0 0}$ \\
\hline Land holding size (in & Small & 60 & $\mathbf{5 4 . 0 0}$ \\
\hline acres): & Medium & 30 & $\mathbf{2 7 . 0 0}$ \\
\hline Total landholding & $1($ acre) & 43 & $\mathbf{3 8 . 7 0}$ \\
\hline under rice cultivation & $1.5($ acres $)$ & 47 & $\mathbf{4 2 . 3 0}$ \\
\hline Livestock ownership & small( $1-2)$ & 40 & $\mathbf{3 6 . 0 0}$ \\
\hline & Medium (3-4) & 30 & $\mathbf{2 7 . 0 0}$ \\
\hline & High $(>\mathbf{4})$ & $\mathbf{2 0}$ & $\mathbf{1 8 . 0 0}$ \\
\hline
\end{tabular}


Table.2 Media usage of literate and illiterate farmers in Nagireddyguda village

\begin{tabular}{|c|c|c|}
\hline Media Usage & Illiterates & Literates \\
\hline & RBQ (Rank) & RBQ (Rank) \\
\hline TV & 99.43 (I) & 89.56 (I) \\
\hline Radio & 38.29 (IV) & 43.77 (IV) \\
\hline Phone & $23.43(\mathrm{~V})$ & 23.91 (VI) \\
\hline Cell & 53.71 (II) & 46.46 (III) \\
\hline Video & 5.14 (VIII) & $25.93(\mathrm{~V})$ \\
\hline Computer & 12.00 (VII) & 12.79 (VIII) \\
\hline News Paper & 41.14 (III) & 49.16 (II) \\
\hline Ag. Magazine & $12.57(\mathrm{VI})$ & 17.51 (VII) \\
\hline
\end{tabular}

Table.3 Preference of media use by the farm women for agriculture information

\begin{tabular}{|l|c|c|c|}
\hline \multicolumn{1}{|c|}{ Media } & Freq. & \% & Rank \\
\hline TV & 87 & 78.30 & 1 \\
\hline Radio & 25 & 22.50 & 6 \\
\hline Phone & 21 & 18.90 & 7 \\
\hline Cell & 57 & 51.30 & 3 \\
\hline Video & 28 & 25.20 & 5 \\
\hline Computer & 67 & 60.30 & 2 \\
\hline News Paper & 57 & 51.30 & 3 \\
\hline Ag. Magazine & 38 & 34.20 & 4 \\
\hline
\end{tabular}

Figure.1 Occupational status of the respondents

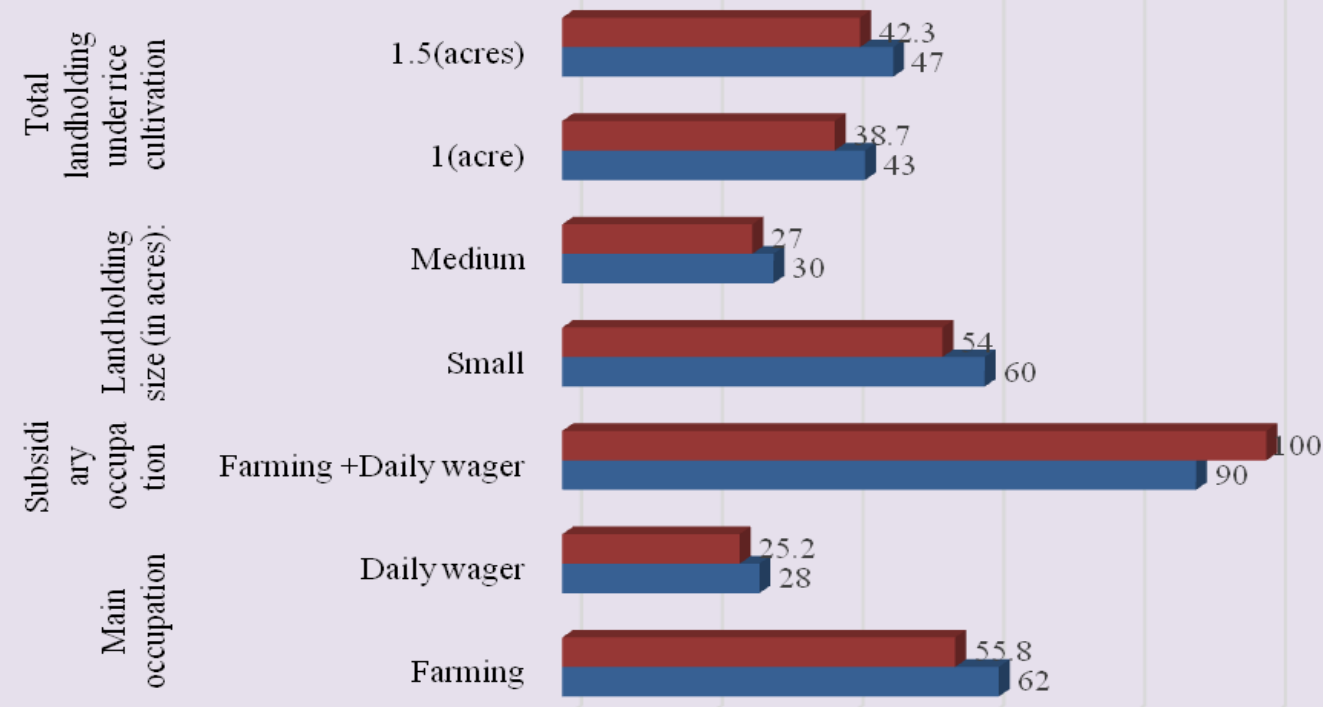




\section{Preference of Media use by the Farm Women for Agriculture Information.}

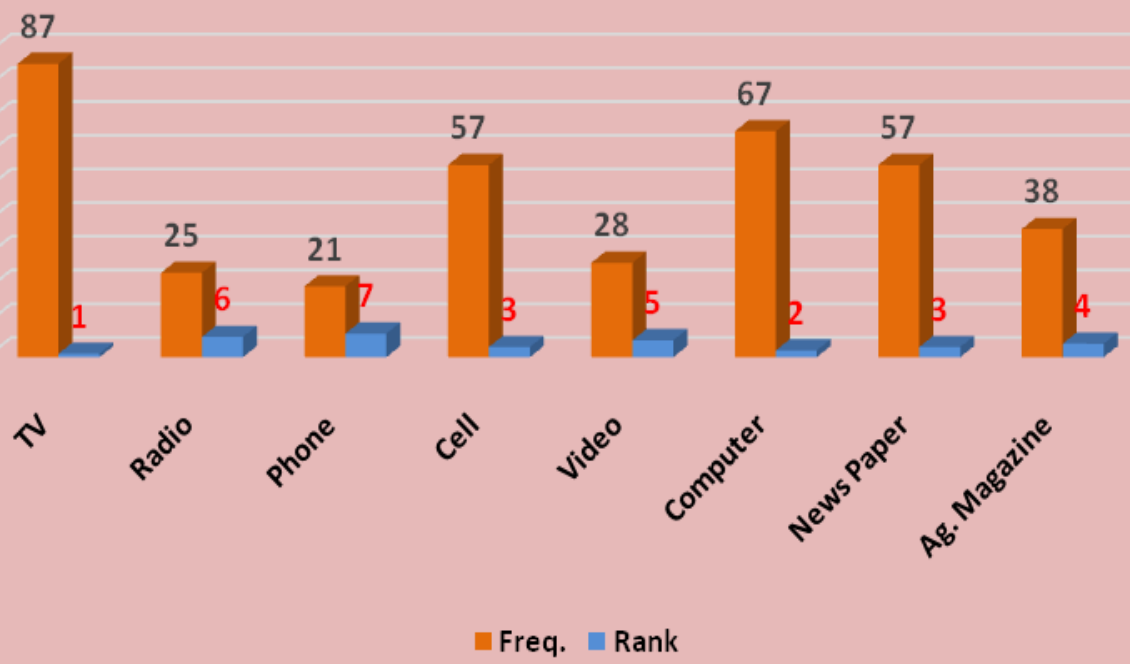

Conclusion of the study are as follows:

It is true that technology is one of the developmental tools. At the same time the new technological inventions have to be properly implemented and train people to operate its advancement for their development. The accessibility of cell phones is creating decision-making capacity and economic liberalization. We have studied that Internet is spreading more between males than females and between young individuals than older ones. Young users were found to use the Internet more frequently for chatting and entertainment than older ones. Furthermore, businessmen were found to have high dependence on the Internet use for commercial purposes. Overall, email access was the main purpose for Internet use.

Rural people's needs are very specific; they need more local information rather than global information. Yet, if the information centers disseminate information on agriculture, domestic developments, local marketing news, government schemes and health care in local languages, this will be very useful for rural people. The study therefore suggests that technological development is an urgent requirement for the socio and economic empowerment of rural women. But at the same time it is very essential element to give time preference of the rural people they can be trained in media usage for their betterment of information needs.

\section{Recommendations}

From a synthesis of the main messages in this paper, we draw the attention to the following issues and recommendations that should be considered

Adequate training and awareness given to the rural female farmers should be promoted by the government.

Create awareness and promote ICT as a tool for development

Build ICT skills for women and girls

Create universal opportunity to access ICT 
Encourage the development of content that is relevant to women.

We need to explicitly emphasize that the rural sector is not only agriculture, and that rural nonfarm income and employment is a major feature in the economic empowerment process of rural men and women.

We need to understand the requirements for ICT investments in rural areas to use gender lenses in order to unveil their potential in favor of rural women's empowerment.

New rural development frameworks need to be designed in order to tackle both the gender gaps and regional disparities within countries.

\section{References}

CharuMalhotra, V.M. Chariar, L.K.Das and P.V. Ilavarasan; ICT for rural development: An Inclusive Framework for e-Governance

Edwin I. Achugbue Lecturer and $\mathrm{PhD}$ student Department of Library and Information Science Delta State University, Abraka, Nigeria Sylvester O. Anie Delta State Polytechnic Ozoro, Nigeria PhD student Delta State University, ICTs and Information Needs of Rural Female Farmers in Delta State, Nigeria, Library Philosophy and Practice 2011 ISSN 1522-0222

Gilles Cliché, 2011, RIMISP - Latin American Center for Rural Development Chile, Rural Women's Empowerment in
Nonfarm Employment Issues for ICT Initiatives and Territorial Policies in Latin America, Enabling rural women's economic empowerment: institutions, opportunities and participation. EGM/RW/2011/EP.7 September 2011

Marcelle, Gillian. 2002. "Gender Equality \& ICT Policy," Presentation at World Bank Digital Divide Seminar Series, Washington, D.C. http://www.worldbank.org/gender/digit aldivide/worldbankpresentation.ppt

Munyna, H. (2000). Application ICTs in Africa's Agricultural Sector: a gender perspective in Rathgeber, E.M., and Adera, E.O. (eds). Gender and the Information Revolution in Africa, Canada: international Development Research Centre.

SatyaNagamani T, Krishna Veni G 2016, ICTs for the Empowerment of Rural Women: A Review, International Journal of Computer Science Trends and Technology. Vol. 7, Issue 2.

TauffiquAhamad, \&Jitendra Kumar Pandery (2014),A Study on Application and Role of ICT in Rural Development, Journal of Emerging Technologies and Innovative Research (JETIR), Volume 1 (6), 455-458.

Vaishnavi Jaywant Deshpande and Rajeshkumar U. Sambhe 2015, ICT Needs for Rural India: A Review, International Journal of Innovative Research in Computer and Communication Engineering, Vol. 3, Issue 10, 9182-9188.

\section{How to cite this article:}

Neela Rani and Uma Jyothi. 2020. Time Preference and Readiness of Farm Women for ICT Usage. Int.J.Curr.Microbiol.App.Sci. 9(06): 4006-4011.

doi: https://doi.org/10.20546/ijcmas.2020.906.469 